\title{
An investigation into the practical application of residential energy certificates
}

\author{
Alan Abela ${ }^{1}$, Mike Hoxley ${ }^{1}$, Paddy McGrath ${ }^{1}$, and Steve Goodhew ${ }^{2}$ \\ ${ }^{1}$ School of Architecture Design and the Built Environment, Nottingham Trent University \\ ${ }^{2}$ School of Architecture Design and Environment, Plyymouth University
}

\begin{abstract}
The Energy Performance of Buildings Directive (EPBD) 2002/91/EC introduced various obligatory requirements intended to achieve the reduction of use of energy resources in buildings and consequentially the reduction of the impact of energy use in buildings. Article 7 of the directive formally specified the current European requirement for the energy certification of buildings. In order to implement this requirement, a general framework for establishing a methodology of calculation of the total energy performance of buildings became necessary. The Maltese methodology for the issuance of energy performance certificates for residential property was developed and introduced by the Ministry of Resources and Rural Affairs in 2010. This methodology differs from that of most other European countries since the energy used for cooling in summer is taken into consideration when carrying out the calculation. Most states only consider the energy for heating in winter for residential energy certificates. A study of the results produced by the Maltese certification process is being used to identify whether the methodology implemented is an accurate tool for environmental monitoring of energy use in Maltese residential property. The analysis is utilised to establish a benchmark for energy use in different residential property typologies. This analysis is developed further to highlight the strengths and weaknesses of the certification procedure as a design tool, and to understand whether the procedure can be effectively applied in the cost optimisation of residential construction or refurbishment projects.
\end{abstract}

\section{INTRODUCTION}

Malta covers just over $300 \mathrm{~km}^{2}$ in land area, and is the smallest and most densely populated country in the European Union. It is also one of the southernmost states in the European Union. Possibly as a result of the mild Mediterranean climate, traditional building practices were not as formally regulated as in other European Union states, and until the implementation of the EPBD in 2006, there were no energy related building regulations (Buhagiar 2007).

Residential property in Malta is generally constructed with a flat concrete roof, with walls in either limestone or concrete brick. The use of insulation in walls is 
not common, although traditional construction consists of a double leaf limestone wall with a central air gap. The application of insulation on roofs is increasingly more widespread although this is a practice which has become established over the past ten years. The introduction of the Minimum Performance of Buildings Regulations in 2006 stipulated maximum U-values for walls at $1.57 \mathrm{~W} / \mathrm{m}^{2} \mathrm{~K}$, and for roofs at $0.58 \mathrm{~W} / \mathrm{m}^{2} \mathrm{~K}$ (Building Regulations Office Malta 2006). The maximum value for windows is $5.8 \mathrm{~W} / \mathrm{m}^{2} \mathrm{~K}$ but these are limited to a maximum of $20 \%$ of the wall area, and lower U-values are required for any increase in the glazed area above the $20 \%$ maximum. These U-values are significantly higher than those stipulated in other EU states.

The national calculation tool for the Energy Performance Rating of Dwellings in Malta (EPRDM) is the basis for the Maltese official procedure for calculating the energy performance of dwellings. The procedure takes account of the net energy required for space heating and cooling, water heating, lighting, and ventilation, after subtracting any savings from energy generation technologies. It calculates the annual values of delivered energy consumption (energy use), primary energy consumption, and carbon dioxide $\left(\mathrm{CO}_{2}\right)$ emissions, both as totals and per square metre of total useful floor area of the dwelling per annum (Ministry for Resources and Rural Affairs Malta 2011).

The procedure consists of a monthly calculation within a series of individual modules. The individual modules contain equations or algorithms representing the relationships between various factors which contribute to the annual energy demand of the dwelling.

The procedure was developed locally and is based on ISO EN 13790:2008 Energy performance of buildings - energy use for space heating and cooling, using a monthly calculation step.

The calculation does not differentiate between new and existing buildings and to date there are no benchmark values established. Some countries have had considerable experience with building certification but these are in North and Central Europe (Poel et al 2007) and their results cannot be applied to a Mediterranean climatic conditions and building types. Registration of Energy Performance Certificates (EPCs) in Malta commenced in January 2011.

After the methodology had been implemented for twelve months, the certificates registered were analysed in order to obtain an understanding of the calculated energy performance of residential property in Malta. 


\section{DATA ANALYSIS}

\subsection{Data Collection}

A total of 249 EPCs were registered with the Ministry for Resources and Rural Affairs during 2011, and this analysis is based on the data extracted from these certificates. The certificate data was obtained from the data registry where all certificates are lodged electronically. The certificates were first analysed on the basis of property type and EPRDM values. Further analysis was carried out on the properties of the building envelope, the properties of the heating, cooling, hot water and lighting systems, and any alternative energy installations.

Forty three certificates were asset type assessments, i.e. based on actual as-built properties, whilst 206 certificates were design type assessments, i.e. assessments based on the plans of a proposed construction. Table 1 shows the distribution of certificates by property type. The majority of certificates are for single storey dwellings in multiple dwelling units, namely flats, maisonettes, and upper floor flats, accounting for just over two thirds (68\%) of certificates issued. Terraced houses and duplex flats account for approximately one quarter $(26 \%)$ of certificates, whilst the quantities of bungalows, villas, and identical units are too low to be statistically significant. The distribution of certificates issued reflects the predominance of flats and maisonettes in the Maltese housing market (National Statistics Office Malta 2005).

Table 1. Distribution of EPCs issued in Malta 2011

\begin{tabular}{lcc}
\hline Type of Dwelling & \multicolumn{2}{c}{$\begin{array}{c}\text { Average EPRDM } \\
\mathrm{kWh} / \mathrm{m}^{2} \mathrm{yr}\end{array}$} \\
\cline { 1 - 2 } Bungalow & 1 & 125.3 \\
Duplex Flat & 19 & 116.2 \\
Flat & 107 & 136.8 \\
Fully Detached Villa & 8 & 98.7 \\
Semi Detached Villa & 2 & 303.5 \\
Maisonette & 40 & 137.8 \\
Identical Units & 4 & 113.1 \\
Terraced House & 46 & 117.2 \\
Upper Floor & 22 & 168.6 \\
\hline
\end{tabular}


The Maltese EPC does not define the energy performance in terms of a band as is the case with many other housing energy certificates, and indeed for white goods also. The certificate denotes the energy performance of the property numerically using the EPRDM (Energy Performance Rating of Dwellings in Malta) indicator. The EPRDM is the calculated value of the primary energy requirement of the dwelling for heating, cooling, lighting and hot water per square metre per annum, net of any alternative energy produced on site. The certificate values of the EPRDM range from 24.0 to $395.7 \mathrm{kWh} / \mathrm{m}^{2} \mathrm{yr}$, with an average value of 133.0 $\mathrm{kWh} / \mathrm{m}^{2} \mathrm{yr}$. This is equivalent to an average Dwelling $\mathrm{CO}_{2}$ Emission Rate (DCER) of $33.2 \mathrm{kgCO}_{2} / \mathrm{m}^{2} \mathrm{yr}$. The calculated energy demand for heating, cooling, lighting and hot water actually varies between 6.95 and $114.69 \mathrm{kWh} / \mathrm{m}^{2} \mathrm{yr}$, with an average value of $37.89 \mathrm{kWh} / \mathrm{m}^{2} \mathrm{yr}$. In order to place these values in context, the requirements for a Passive House in Central Europe are a maximum of 120 $\mathrm{kWh} / \mathrm{m}^{2} \mathrm{yr}$ of primary energy for heating, hot water and household electricity (Passive House Institute 2010).

Table 1 demonstrates that the average EPRDM values for flats and maisonettes (single storey dwellings) are remarkably comparable at 136.8 and $137.8 \mathrm{kWh} / \mathrm{m}^{2} \mathrm{yr}$ respectively. Similarly, terraced houses, which have two or more storeys, and duplex flats have average EPRDM values of 117.2 and $116.2 \mathrm{kWh} / \mathrm{m}^{2} \mathrm{yr}$ respectively. As expected, properties on the upper floor have a higher average EPRDM of $168.6 \mathrm{kWh} / \mathrm{m}^{2} \mathrm{yr}$.

The subsequent analysis presented hereunder is based on the extraction of the relevant figures by the lead author of this paper from the 249 certificates registed in Malta during 2011.

\subsection{Alternative Energy}

Examination of the makeup of the calculated energy values shows that the contribution of photovoltaic and wind turbine installations accounts for just $0.5 \%$ of domestic primary energy demand, with the total contribution from alternative energy rising to $1 \%$ due to an energy benefit in the methodology for the use of second class water, claimed by 63 properties $(25 \%)$. Just five properties, all at the design stage, have included a photovoltaic installation and two of these five also included a wind turbine. The contribution of solar water heating is intrinsic to the domestic hot water calculation within the methodology and is not identified separately as 'alternative energy'. This also applies to the contribution from heat pumps for space heating. 


\subsection{Heating}

The main component of the primary energy requirement calculated for Maltese dwellings is heating, which accounts for over $40 \%$ of the demand, followed by cooling at $30 \%$, and domestic hot water at $18 \%$. Lighting contributes to $10 \%$ of the primary energy demand.

The relatively high proportion of primary energy demand arising from heating can be attributed to the fact that Maltese homes typically do not have a heating system installed, and hence the default heating system, electric heating, is applied. Out of the certificates submitted, 109 (44\%) had electric heating, $133(53 \%)$ had heat pumps with an average coefficient of performance of 3.67, and just 7 (3\%) had heating systems using gas or wood. The average EPRDM for all properties with heat pumps installed reduces to $91.15 \mathrm{kWh} / \mathrm{m}^{2} \mathrm{yr}$ whilst the average EPRDM for properties with the default electric heating installation is practically double at $184.44 \mathrm{kWh} / \mathrm{m}^{2} \mathrm{yr}$.

Fig. 1. Breakdown of Residential Delivered Energy and Primary Energy by Component

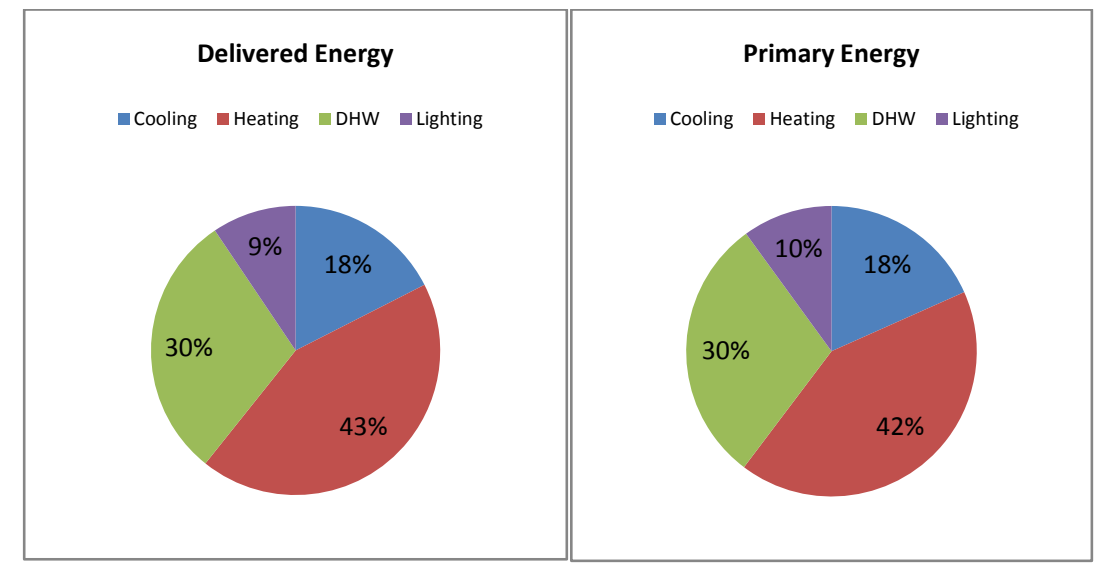

\subsection{Domestic Hot Water}

The second largest component of the primary energy load is domestic hot water. Only $60(24 \%)$ of the certificates include solar water heaters. The average EPRDM for properties with solar water heaters is $102.2 \mathrm{kWh} / \mathrm{m}^{2} \mathrm{yr}$, with an average primary energy requirement for water heating of $7.44 \mathrm{kWh} / \mathrm{m}^{2} \mathrm{yr}$ whilst the average EPRDM for the 189 properties (76\%) without solar heating installed is $142.7 \mathrm{kWh} / \mathrm{m}^{2} \mathrm{yr}$ with a primary energy requirement of $49.23 \mathrm{kWh} / \mathrm{m}^{2} \mathrm{yr}$. 
Sixteen properties $(6.4 \%)$ use gas as a fuel for water heating whilst all the others use electricity.

\subsection{Cooling}

Whilst cooling accounts for $18 \%$ of the primary energy in residences, this is generally provided by a heat pump for both cooling and heating, having a positive effect on the overall energy performance. The default coefficient of performance for cooling was applied in 56 of the certificates, implying that these properties either did not have a cooling system installed or planned, or that data on the cooling system was not available. The overall average coefficient of performance for cooling was 3.02 which is marginally higher than the default value of 2.8 . The average primary energy for cooling is $24.64 \mathrm{kWh} / \mathrm{m}^{2} \mathrm{yr}$.

\subsection{Lighting}

The lighting load is $10 \%$ of the overall primary energy with an average value of $13.45 \mathrm{kWh} / \mathrm{m}^{2} \mathrm{yr}$. This value corresponds to an average of $80 \%$ of all light fittings installed indicated as being fitted with energy saving bulbs.

\subsection{Building Envelope}

In order to investigate the effect of the opaque building envelope, the sum of the product of the U-Values (U) and areas (A) for the envelope elements was plotted against the sum of the heating and cooling loads. Both parameters were divided by the total floor area (TFA) of the property. Figure 2 does not show any direct correlation between the properties of the opaque building envelope (UA) and the heating and cooling demand. This could be due to the effect of solar radiation which contributes considerably to reducing the heating load in winter, as well as driving the cooling load up in summer. Investigation of the effect of the glazing properties and orientation is an area for further analysis by the authors of this paper.

Fig. 2. UA/TFA plotted against Heating and Cooling Load/TFA 


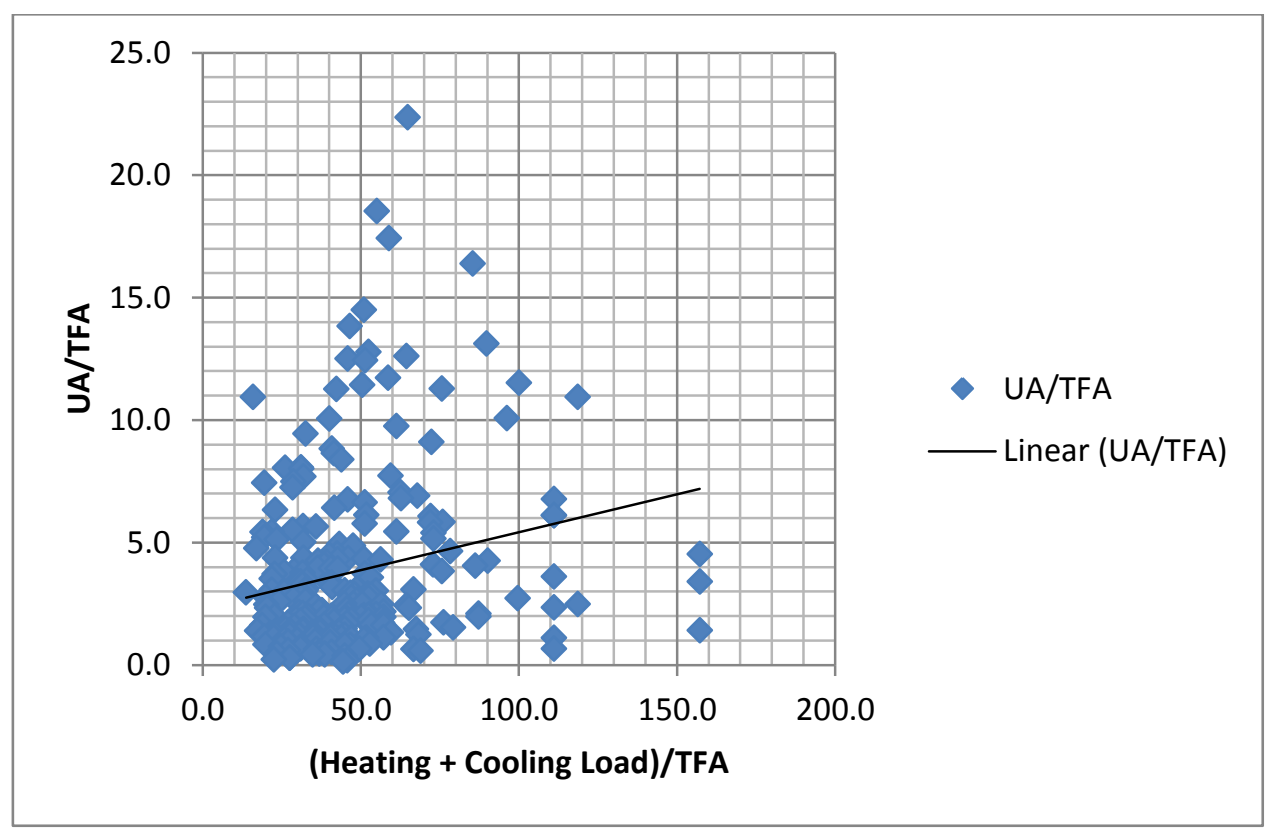

\section{DEVELOPMENT OF BENCHMARKS}

Prior to the introduction of the EPRDM methodology, no formal assessment of the energy use in Maltese dwellings was available Although the directive indicates that the certificate should indicate typical values for comparison purposes, these values have not been provided. On the basis of this analysis, carried out on the first set of 249 certificates registered at the Ministry of Resources and Rural Affairs during 2011, the following benchmark values are being proposed for different Maltese dwelling types.

Flats and Maisonettes

Terraced Houses and Duplex Apartments

Upper Floor Properties

$$
\begin{aligned}
& 137 \mathrm{kWh} / \mathrm{m}^{2} \mathrm{yr} \\
& 117 \mathrm{kWh} / \mathrm{m}^{2} \mathrm{yr} \\
& 168 \mathrm{kWh} / \mathrm{m}^{2} \mathrm{yr}
\end{aligned}
$$

The data collected was insufficient to propose values for bungalows, semidetached and fully detached villas. However it is clear that the properties of the building envelope are not the most significant variables affecting the EPRDM. It is therefore proposed that bungalows can be categorised together with upper floor properties, whilst semi- and fully-detached villas be considered under the same category as terraced houses and duplex apartments. 


\subsection{Comparative Values}

From the certificate data collected, the average floor area for Malta is calculated at $136 \mathrm{~m}^{2}$, and the average delivered energy is $5,175 \mathrm{kWh} / \mathrm{yr}$. This is the value of the energy delivered to the residence for heating, cooling, lighting, and domestic hot water excluding appliances. The primary source of energy to Maltese dwellings is electricity, with LPG also used for some heating and cooking. In a previous study on energy use in Maltese dwellings (Abela 2011), the actual average delivered energy to Maltese homes was estimated at approximately $6,000 \mathrm{kWh} / \mathrm{yr}$. This figure is for all consumption including appliances.

Table 2. Comparison of statutory limitations for primary energy consumption in dwellings

\begin{tabular}{|c|c|c|}
\hline Category & Primary Energy & Constituent Components \\
\hline Passive house & 120 & $\begin{array}{l}\text { heating, cooling, hot water, household elec- } \\
\text { tricity }\end{array}$ \\
\hline $\begin{array}{l}\text { France RT } 2005 \text { Region H3 } \\
\text { Electric Heating including heat } \\
\text { pumps }\end{array}$ & 130 & heating, cooling, hot water \\
\hline $\begin{array}{l}\text { France RT } 2005 \text { Region H3 } \\
\text { Heating using fossil fuels }\end{array}$ & 80 & heating, cooling, hot water \\
\hline France RT 2012 Region H3 & 40 & $\begin{array}{l}\text { heating, cooling, hot water, lighting, auxilia- } \\
\text { ries }\end{array}$ \\
\hline $\begin{array}{l}\text { Spain maisonette/apartment } \\
\text { Almeria mainland }\end{array}$ & 52 & heating, cooling, hot water \\
\hline $\begin{array}{l}\text { Spain single family dwelling } \\
\text { Almeria mainland }\end{array}$ & 79 & heating, cooling, hot water \\
\hline $\begin{array}{l}\text { Malta maisonette/apartment } \\
\text { Proposed current benchmark }\end{array}$ & 137 & $\begin{array}{l}\text { heating, cooling, hot water, lighting, auxilia- } \\
\text { ries }\end{array}$ \\
\hline $\begin{array}{l}\text { Malta all typologies } \\
\text { Proposed future benchmark }\end{array}$ & 70 & $\begin{array}{l}\text { heating, cooling, hot water, lighting, auxilia- } \\
\text { ries }\end{array}$ \\
\hline Italy Region A and B & 40 & $\begin{array}{l}\text { cooling only (not yet implemented in meth- } \\
\text { odology) }\end{array}$ \\
\hline
\end{tabular}




\section{DISCUSSION}

Analysis of the certificates submitted shows that the most effective measures in reducing the calculated primary energy requirements of Maltese dwellings are the use of heat pumps for heating and the use of solar water heaters. Just over half of certified properties have heat pumps installed whilst just under a quarter have solar water heating installed. The average EPRDM for properties with both heat pumps and solar water heating installed calculated on the basis of the existing data is $57.2 \mathrm{kWh} / \mathrm{m}^{2} \mathrm{yr}$. In view of the fact that not all properties have access to sufficient roof space to install a solar water heater, the target EPRDM value for proposed benchmarking is $70 \mathrm{kWh} / \mathrm{m}^{2} \mathrm{yr}$ as an immediate short-term goal for 2016, representing a reduction in calculated energy use of nearly $50 \%$ over the current average value.

The methodology used for calculation of primary energy use in Maltese dwellings suggests that passive energy saving measures are not as effective as active measures. The mild climate with relatively low temperature differences between indoors and outdoors results in the benefits of reducing U-values not being as pronounced as in more northern climates. Shading techniques could be used to reduce cooling loads, but the methodology indicates a corresponding increase in the winter heating loads. This could be due to the fact that the methodology does not allow for the use of a monthly shading factor but only permits the input of an annual value. Both shading and ventilation are areas where further development of the methodology could result in the production of more accurate results.

\section{CONCLUSIONS}

The certification methodology applied in Malta provides a reasonable approximation of the actual pattern of energy use in dwellings. The results obtained from the first group of certificates both match actual data and fall within the bands indicated by other regions with a similar climate (CSTB 2006) (Salmerón et al 2011). The calculation procedure is based on EN 1SO I3790:2008, and it is therefore logical to expect that although the calculation gives correct results on an annual basis, the results for individual months close to the beginning and the end of the heating and cooling season can have large relative errors (BSI 2008), although this has not been verified for Mediterranean climates. In the Mediterranean region the relationships between energy demand calculation and building design and operation become more complex (Tronchin and Fabbri 2008). 
The data analysis indicates benchmark values that can be considered representative of average Maltese properties. These benchmarks can be applied to provide a ranking for certified properties, allowing owners and developers to place their properties on a scale. The benchmark values identified are comparable to those established by other Mediterranean countries with more mature certification systems (see Table 2).

The results of this analysis indicate that the most effective interventions for improving the energy performance of Maltese dwellings are the use of heat pumps for heating and solar water heating for domestic hot water. Whilst these will not bring residential energy consumption down to the 'Nearly Zero' value indicated as a target in the recast directive 2010/31/EC , these two measures together can result in a reduction of the order of $50 \%$. The recast also places an emphasis on cost optimization, and the introduction of 'active' measures for energy efficiency is expected to be more cost effective than passive measures for existing housing.

Whilst research in other countries indicates that discrepancies are expected between the calculated energy consumption of homes and what actually happens when people live in them, it is acknowledged that these discrepancies are confusing for a household that needs to use the EPC when applying for subsidies, for example (Sunikka-Blank and Galvin 2012). Further investigation into the data is required to examine the effect of energy saving measures in greater detail, specifically on the operation of the property on a monthly basis, and consequently to understand whether these are being handled accurately by the calculation methodology. In most circumstances, the Energy Performance Certificate is the only available tool for the public to gauge the energy efficiency of a residence, and hence the accuracy of the certificate has economic and social implications.

\section{REFERENCES}

Abela A, Hoxley M, McGrath P, Goodhew S (2011) A comparative study of the implementation of the energy certification of residential properties in Malta in compliance with the Energy Performance of Buildings Directive. In Passive House Conference, Malta.

Buhagiar V (2007 ) Technical Improvement of Housing Envelopes in Malta. In: Braganca L et al (ed) COST C16 Improving the Quality of Existing Urban Building Envelopes: Facades and Roofs, Delft University Press, Netherlands

British Standards Institute (2008) Energy performance of buildings - Calculation of energy use for space heating and cooling (ISO 13790:2008). British Standards Institute.

Building Regulations Office Malta. (2006) Technical Guide F: Conservation of Fuel Energy and Natural Resources. Valletta, Malta.

Centre Scientifique et Technique du Bâtiment (CSTB) (2006) Réglementation Thermique 2005 Th-CE.

Centre Scientifique et Technique du Bâtiment (CSTB) (2010) Réglementation Thermique 2012 Th-CE.

European Parliament and Council (2002) Energy Performance of Buildings Directive 2002/91/EC. Brussels, Belgium.

European Parliament and Council (2010) Energy performance of buildings (recast) 2010/31/EC. Brussels, Belgium. 
Ministry for Resources and Rural Affairs Malta (2011) Implementation of the EPBD in Malta Status in November 2010 In: Maldonado E (ed) Implementation of the Energy Performance of Buildings Directive, European Union, Brussels, Belgium.

National Statistics Office (2005) Census of Population and Housing 2005 Volume 2 Dwellings. Government Press, Malta.

Passive House Institute (2010) Active for more comfort: The Passive House. Darmstadt, Germany.

Poel B, van Cruchten G, Balaras CA (2007) Energy performance assessment of existing dwellings. Energy and Buildings 39: 393-403

Salmerón JM, Cerezuela A, Salmerón R (2011) Escala de califación energética para edificios existentes. Instituto para la Diversificacion y Ahorro de la Energía, Madrid Spain.

Sunikka-Blank M, Galvin R (2012) Introducing the prebound effect: the gap between performance and actual energy consumption. Building Research \& Information 40:3, 260-273

Tronchin L, Fabbri K (2007) Energy performance building evaluation in Mediterranean countries: Comparison between software simulations and operating rating simulation. Energy and Buildings 40:1176-1187 